\title{
Diatom defence: Grazer induction and cost of shellthickening
}

\author{
Grønning, Josephine; Kiørboe, Thomas
}

Published in:

Functional Ecology

Link to article, DOI:

$10.1111 / 1365-2435.13635$

Publication date:

2020

Document Version

Peer reviewed version

Link back to DTU Orbit

Citation (APA):

Grønning, J., \& Kiørboe, T. (2020). Diatom defence: Grazer induction and cost of shellthickening. Functional Ecology, 34(9), 1790-1801. https://doi.org/10.1111/1365-2435.13635

\section{General rights}

Copyright and moral rights for the publications made accessible in the public portal are retained by the authors and/or other copyright owners and it is a condition of accessing publications that users recognise and abide by the legal requirements associated with these rights.

- Users may download and print one copy of any publication from the public portal for the purpose of private study or research.

- You may not further distribute the material or use it for any profit-making activity or commercial gain

- You may freely distribute the URL identifying the publication in the public portal

If you believe that this document breaches copyright please contact us providing details, and we will remove access to the work immediately and investigate your claim 


\section{Functional Ecology}

\section{Diatom defence: Grazer induction and cost of shell-}

\section{thickening}

Josephine Grønning and Thomas Kiørboe

Centre for Ocean Life, Technical University of Denmark, DTU Aqua, Kemitorvet B201, Kongens Lyngby, DK-2800, Denmark

Corresponding Author email: jbgr@aqua.dtu.dk

\section{Acknowledgements}

We thank Erik Selander and Fredrik Ryderheim for help with copepodamide extraction and Colin Stedmon for help with Si-analysis. We further thank Erik Selander for valuable discussions. This work was supported by the Centre for Ocean Life funded by the Villum Foundation and by the Gordon and Betty Moore Foundation (grant no. 5479).

\section{Author's contributions}

JG and TK conceived the ideas and designed methodology;

JG collected the data;

JG and TK analysed the data;

JG and TK wrote the manuscript.

\section{Data availability statement}

Data available from the Dryad Digital Repository: https://doi.org/10.5061/dryad.v6wwpzgst

(Grønning \& Kiørboe 2020).

This article has been accepted for publication and undergone full peer review but has not been through the copyediting, typesetting, pagination and proofreading process, which may lead to differences between this version and the Version of Record. Please cite this article as doi: $\underline{10.1111 / 1365-2435.13635}$

This article is protected by copyright. All rights reserved 
JOSEPHINE GRØNNING (Orcid ID : 0000-0001-9440-5129)

Article type : Research Article

Editor : Julia Cooke

Section : Plant-Animal Interactions

\section{Abstract}

1. Diatoms account for $40 \%$ of the ocean primary production and play a key role in the oceans' ability to sequester carbon. The evolutionary success of diatoms and their role in ocean biogeochemistry are related to the siliceous shell that provide partial protection against grazing.

2. The structure and function of phytoplankton communities are governed by environmental constraints and organismal trade-offs. Defence mechanisms may help explain the high diversity of phytoplankton (incl. diatoms) in the ocean, but only if the defence comes at a cost. Defence costs have been notoriously difficult to demonstrate and quantify in marine phytoplankton.

3. Here, we demonstrate for seven species of planktonic diatoms that their shell thickens and their growth rate declines when cells are exposed to chemical cues from copepods, important predators of diatoms. The responses are proportional to the concentration of grazer cues, but are also highly variable, both between and within species.

4. At our standard experimental condition, the typical decline in growth rate is $10 \%$, and the typical increase in cellular biogenic silica is $16 \%$. The latter value corresponds to a decline in grazing mortality due to small copepods of $11 \%$. Thus, silification in response to grazers is exactly warranted.

5. The similar magnitude of the costs and benefits of silification suggests a flat fitness landscape along the competition-defence axis. This may help explain the high diversity of coexisting diatoms in the ocean.

6. The significant but variable contribution of diatoms to the downward flux of organic carbon in the ocean depends to a large extent on the silica content of the cells. This is 
due less to the ballasting effect of silica, but mainly to the different life histories of more or less defended cells that are governed by evolutionary adaptations and - as demonstrated here - plastic responses to grazers.

Keywords: Defence trade-offs, copepodamides, inducible defence, silification, shell thickness, co-existence 


\section{Introduction}

Predator-prey interactions are key in shaping ecosystem structure and function (Belgrad and Griffen, 2016; Creel, 2018; Lima, 1998). In the oceans, zooplankton predation is believed to be an important mechanism maintaining phytoplankton species diversity by allowing the coexistence of defence- and competition specialists, as demonstrated both theoretically (Cadier et al., 2019; Ehrlich and Gaedke, 2018; Våge et al., 2018) and experimentally (Leibold et al., 2017; McCauley and Briand, 1979). Indeed, phytoplankton have evolved a large range of defence mechanisms, ranging from morphological to biochemical or behavioural (Pančić and Kiørboe, 2018; van Donk et al., 2011). However, the costs and benefits of these different defence mechanisms have rarely been quantified, or even demonstrated, and hence the defence trade-offs hypothesised to promote diversity are most often unknown (Pančić and Kiørboe, 2018)

Diatoms are a diverse and important group of phytoplankton. They account for about $20 \%$ of the Earths photosynthesis (Armbrust, 2009) and are a major contributor to the biological carbon pump (Smetacek, 1999). Diatoms are characterised by an external silica shell, the frustule, that has many hypothesised functions, ranging from enhancement of light and nutrient harvesting to mechanical protection of the cell against grazing (Hamm et al., 2003; Mitchell et al., 2013; Romann et al., 2015). The defensive role of the shell has been suggested based on its unparalleled strength (Hamm et al., 2003; Milligan and Morel, 2002; Raven and Waite, 2004; Smetacek, 2001). The shell has the highest mechanical strength relative to its density of any known biological material (Aitken et al., 2016) and the consequent force required to crush the cell wall is remarkable (Hamm et al., 2003; Wilken et al., 2011). Recent experiments have indeed demonstrated that the shell provides partial protection against copepod grazing (Liu et al., 2016; Pančić et al., 2019). Thus, a 6-fold increase in silica content in a variety of diatoms decreased the predation mortality due to a copepod grazer by 4-fold and entirely prevented small copepod nauplii from consuming the diatoms (Pančić et al., 2019).

For predation to promote diversity, defence must come at a cost. Else, defended species would outcompete less defended species, and all species would be equally defended. Defence costs have been notoriously difficult to quantify in phytoplankton and the magnitude of the costs may depend on whether or not the cells are resource limited (Pančić and Kiørboe, 
2018). However, many defence mechanisms in phytoplankton are inducible, i.e., are harnessed or intensified in response to grazer cues (Selander et al., 2019), suggesting significant costs to the defence (Karban, 2011; Tollrian and Harvell, 1999). There is some experimental evidence that silification in diatoms is inducible by grazer cues, suggesting that silification is costly (Pondaven et al., 2007). The biochemical costs of silica deposition in the shell are minute (Raven, 1983), but the deposition of silica is rate-limited. Thus, slower growth allows heavier silification (Martin-Jézéquel et al., 2000) and one may hypothesise that heavier silification may be at the cost of slower growth (Pančić et al., 2019). This, however, remains to be tested.

Here, we examine the potential inducibility and cost of silification. We hypothesise that diatoms increase their contents of biogenic silica (shell thickness) and decrease their growth rate in response to diffusible copepod cues. We expose cells grown under both silica replete and deplete conditions to copepod grazer cues and record potential changes in silica contents and growth rates of the cells. To examine the generality of this hypothesis, we test seven different species of diatoms. We demonstrate increases in silica content and decreases in growth rates of induced vs. non-induced cells in all species tested, but also that the response is highly variable both within and between species.

\section{Materials and Methods}

\section{Diatom cultures and culturing conditions}

We examined seven species of diatoms: Amphiprora paludosa (CCMP125), Cyclotella cryptica (CCMP331), Cyclotella meneghiniana (CCMP336) (which later DNA analysis demonstrated to be a different strain of C. cryptica), Ditylum brightwellii (unknown strain), Navicula incerta (CCMP542), Nitzschia laevis (CCMP559), and Thalassiosira weissflogii (unknown strain). None of the species are known to produce toxins. Thalassiosira weissflogii and $D$. brightwellii were obtained from DTU Aqua, Denmark, while the other species were obtained from NCMA at Bigelow Laboratory, Maine. All diatoms were grown in B1 medium with silica ( $500 \mu \mathrm{M} \mathrm{Si}$ ) (Hansen, 2007) at $16^{\circ} \mathrm{C}$ and a L:D cycle of $16: 8\left(120 \mu \mathrm{mol} \mathrm{m} \mathrm{s}^{-2} \mathrm{~s}^{-1}\right)$. Cells in exponential growth were used to initiate experiments. Experiments were run in continuous light at the same light intensities and temperature conditions as the cultures.

\section{Copepod cues}

This article is protected by copyright. All rights reserved 
We used two different sources of copepod cues, either filtered water from a culture of copepods (Acartia tonsa), or copepod signal molecules extracted from freeze dried copepods, Calanus finmarchicus ('Copepodamides', Selander et al., 2015). Copepodamides induce a variety defence mechanisms in phytoplankton (Selander et al., 2019).

The filtrate was water from a continuous culture of the copepod Acartia tonsa with about 100 individuals $\mathrm{L}^{-1}$ and maintained on a mixture of phytoplankton (Heterocapsa triquetra, Rhodomonas salina and Thalassiosira weissflogii). Culture water was first passed through a $20-\mu \mathrm{m}$ filter and then through a GF/C filter. The filtrate with nutrients added to B1 concentrations was used in experiments immediately after filtration and served as a positive control.

Copepodamides were purified from freeze dried Calanus finmarchicus as described in Selander et al. (2015). Briefly, C. finmarchicus were extracted with methanol and crude extracts were subjected to liquid-liquid partitioning between methanol/water and heptane. The methanol-soluble fraction was then fractionated on C18 SPE columns. Impurities were eluted in $70 \%$ methanol (aq) and copepodamides in $100 \%$ methanol. Finally, the methanol extract was concentrated by rotary evaporation, dissolved in a small volume and fractionated by reversed phase gradient elution HPLC (Selander et al 2015). The copepodamide content of each fraction was determined through direct infusion mass spectrometry. Positive fractions were pooled and the final concentration determined by mass spectrometry.

The copepodamides were dissolved in methanol and added to the empty culture flasks, and the methanol was then evaporated under a stream of nitrogen (Selander et al., 2015). Diatom cultures were then immediately added. Nominal concentrations of copepodamides varied between 1-10 nM, but effective concentrations were at least 2 orders of magnitude less due to a short half-life time and unknown losses (Selander et al., 2019).

\section{Experimental designs}

We ran three different types of induction experiments to test the effect of exposure time, copepodamide concentration, and nutrient depletion on the potential inducibility. (1) Repeated batch experiments, where diatoms were exposed to copepod cues over a period of 7-11 days; (2) dose-response batch experiments, where diatoms were exposed to different concentrations of copepodamides for 48 hours; and (3) continuous culture experiments with 
exposure to copepodamides (Table 1). Nutrients were replete in the two batch experiments, while silica was limiting in the chemostat experiment. Cell concentrations and sizes (volume) were measured by a Coulter Counter (Beckman Coulter, Multisizer 3, USA). Cells of $C$. cryptica and $C$. meneghiniana tended to aggregate during incubations, and samples $(20 \mathrm{~mL})$ were therefore sonicated for 120 s before counting.

\section{Repeated batch experiments}

In these experiments, cell cultures were diluted daily to the same, low cell concentration with fresh growth medium such that the cells never were resource limited. Slowly growing species (D. brightwellii) were diluted only every 2 nd day. Control and treatment cultures were run in duplicate (D. brightwellii and T. weissflogii) or triplicate (all others). In experiments with copepodamides, cultures were transferred to new, freshly coated culture bottles every day with a nominal concentration of copepodamides of $10 \mathrm{nM}$. Control cultures were similarly transferred to bottles coated with pure methanol. In experiments with filtrate, the slowgrowing species (D. brightwellii) were diluted with fresh filtrate by minimum $20 \%$, and fast growing species (T. weissflogii) by minimum $50 \%$. Samples for cell counts for growth rate estimation and measurements of biogenic silica in cells and dissolved silica concentrations were taken daily, except from D. brightwellii in filtrate, where samples were taken daily initially and every second day.

\section{Dose-response experiments}

For the dose-response experiments, triplicate diatom cultures were grown at four different nominal concentrations $(0,2,5$ or $10 \mathrm{nM})$ of copepodamides for $48 \mathrm{~h}$. Bottles were coated at the start and after $24 \mathrm{~h}$ as described above. Cell concentrations were measured at 24 and $48 \mathrm{~h}$ for growth rate estimates and samples for biogenic silica concentrations were taken at start and termination of the experiment. Cell densities were low throughout the incubation and cultures never became resource limited.

\section{Continuous culture experiment}

To test silification and growth rates of diatoms in response to copepodamides under silica limitation, continuous culture experiments were carried out with two diatom species $(T$. weissflogii and A. paludosa). Cultures were first grown to $\sim$ steady state in chemostats with a continuous inflow of B1 medium with a low silica concentration of $20 \mu \mathrm{M}$ to ensure that silica became limiting. The dilution rate was $0.66 \mathrm{~d}^{-1}$. During the subsequent 5 days, triplicate 
chemostats of each species were exposed to copepodamides along with triplicate controls. Cultures were daily transferred to new bottles, freshly coated with methanol containing copepodamides $(10 \mathrm{nM})$ or pure methanol, as above. Each culture bottle was aerated to ensure complete mixing and to prevent carbon limitation. Samples for cell concentration, biogenic silica content, and dissolved silica were collected every $24 \mathrm{~h}$. To avoid any silica contamination, no glassware was used during the experiments.

In a chemostat at steady state the cell growth rate is fixed by the dilution rate $(D)$, and a growth rate response therefore instead materialises as a change in the concentrations of cells and dissolved silica in the culture bottle. Thus, a decrease in growth in response to copepod cues would result in lower cell concentration and higher silica concentration in the culture. Specifically, by assuming Michaelis-Menten kinematics to describe the functional response of growth rate to silica concentration, one can estimate the maximum growth rate $\left(\mu_{\text {Max }}\right)$ from the steady state cell $(\hat{B})$ or ambient silica $(\hat{S})$ concentration in the culture (both in units of $\mu \mathrm{M}$ silica) (Ryderheim et al., 2020):

$$
\mu_{M a x}=\frac{D \alpha\left(S_{i}-\hat{B}\right)}{\alpha\left(S_{i}-\hat{B}\right)-D} \text { or } \mu_{M a x}=\frac{\hat{S} \alpha D}{(\hat{S} \alpha-D)}
$$

Where $D$ is the dilution rate, $\alpha$ the affinity for silica $\left(0.41 \mathrm{~L} \mathrm{~d}^{-1} \mu \mathrm{mol} \mathrm{Si}{ }^{-1}\right.$, Paasche, 1973$)$, and $S_{\mathrm{i}}$ the concentration of silica in the inflow growth medium. This allows one to compare the maximum growth rate of induced relative to non-induced cells. While the estimate of the maximum growth rate is sensitive to the (assumed) magnitude of the affinity, the relative change is not.

\section{Biogenic silica analysis}

For analysis of cellular biogenic silica content, the method of Paasche (1980) and Pančić et al. (2019) was followed. $10 \mathrm{~mL}$ samples were filtered on 3- $\mu \mathrm{m}$ polycarbonate filters and washed twice with acidic MilliQ water to reduce the dissolution of silica. The $\mathrm{pH}$ of this acidic MilliQ water was adjusted by adding hydrochloric acid until a pH of 5.0. Hereafter, the filters were dried at $65^{\circ} \mathrm{C}$ for $90 \mathrm{~min}$ and stored at $-20^{\circ} \mathrm{C}$ until dissolved in $15 \mathrm{~mL} 0.5 \%(\mathrm{w} / \mathrm{v})$ sodium carbonate solution and reheated at $85^{\circ} \mathrm{C}$ for $90 \mathrm{~min}$. When cooled, the $\mathrm{pH}$ was adjusted to 5 - 6 by adding concentrated sulfuric acid and the reactive silica concentration was analysed in a SmartChem 200 wet chemistry analyser (Unity Scientific, MA) following 
the molybdate method of Strickland and Parsons (1972). For analysis of dissolved silica in cultures and medium, $10 \mathrm{~mL}$ samples were passed through a $0.2 \mu \mathrm{m}$ syringe filter and stored at $-20^{\circ} \mathrm{C}$ until analysed in a SmartChem 200 as above. Biogenic silica content is here expressed per cell volume, because the strength of the shell scales approximately with silica per volume rather than with silica per surface area (Pančić et al., 2019).

\section{Statistical analysis}

The dose response relationship between copepodamide concentration and silica content, growth rate, or cell volume was analysed with linear regression. The effects of copepodamides in batch and chemostat experiments were analysed with a linear mixed model. The models took treatment and time as fixed effects and replicate as a random effect. Day 0 is not included in the statistical analysis of repeated batch or chemostat experiments.

To test within each approach whether the proportion of experimental trials that responded positively to induction was significant, a binomial one-tailed test was used. A t-test was used to further test whether the overall mean responses were different from zero. A significance level of $5 \%$ was used throughout. All statistical analysis was performed in R (Version 1.2.5001). All mean values in this study are presented with \pm standard deviation.

\section{Results}

\section{Dose-response experiments}

Of the seven species tested in the dose-response experiments, six showed a significant increase in silica per cell volume with increasing concentration of copepodamides (Fig. 1, Table 2, Table S1). The increase varied from 3 - $36 \%$ compared to controls (Fig. 1, Table $\mathrm{S} 1)$. The effect of copepodamides on growth was more variable; 3 species significantly decreased their growth with increasing amount of copepod cues whereas the other four did not. Finally, cell sizes (volume) decreased by $3-12 \%$ in response to copepodamides in 4 out of 7 species. Two species showed the opposite effect after $48 \mathrm{~h}$ and increased volume by 3 $11 \%$. The last one, T. weissflogii, did not change volume in response to copepodamides.

When comparing the results across all species tested in the dose-response experiments, the proportion of experiments showing increased silica content of cells exposed to copepod cues is significant (binominal test, $\mathrm{p}=0.016$ ) with an overall mean change of $18.7 \pm 11.1 \%$, 
which is also significantly different from zero $(p=0.004$, Fig. 2a). The proportion decreasing growth rate is not significant ( $\mathrm{p}=0.18$ and $\mathrm{p}=0.06$, respectively) and neither is the overall mean change of $-17.3 \pm 38.7 \%(p=0.1171)$ (Fig. 2b). Finally, the proportion of experiments with decreased cell volume is significant $(\mathrm{p}=0.013)$, as is the overall mean change of $-3.8 \pm$ $6.5 \%(\mathrm{p}=0.050)$.

\section{Repeated batch experiments}

Repeated batch experiments tested the inducibility of a species over multiple cell divisions (7 - 11 days). In all species tested in these experiments, the silica content per cell volume was higher in induced than non-induced cells, and the difference was statistically significant in 4 of 6 species (Fig. 3, Table 3). The average relative increase in silica content in induced cells over the course of the experiments was comparable to the results in the dose response experiments and varied between 5 - $35 \%$ (Table 3 ). The growth rate and cell volume of induced cells were significantly reduced in 3 and 4 out of 6 species, respectively (Table 3 ).

When comparing across all species and treatments in the repeated batch experiments, the proportion of cells with higher silica content in induced relative to non-induced cells is significant ( $\mathrm{p}=1.405 \mathrm{e}-07$ ) (Fig. 4a). The mean change in silica is $16.3 \pm 17.3 \%$, which is statistically different from zero $(\mathrm{p}=1.55 \mathrm{e}-07)$. Likewise, the proportion of cells decreasing their growth rate or cell volume $(\mathrm{p}=0.04877$ and $\mathrm{p}=0.0004$, respectively), and their overall means of $-10.1 \pm 21.5 \%(\mathrm{p}=0.003)$ and $-1.9 \pm 3.6 \%(\mathrm{p}=0.0008)$, respectively, are all statistically significant (Fig. 4b-c).

\section{Continuous culture experiments}

Two species, T. weissflogii and A. paludosa, were tested in a continuous culture set-up with silica as the limiting resource (Fig. 5). Only T. weissflogii showed a significant response to the presence of copepodamides (Table 4). As hypothesised, induced cells had a significantly higher biogenic silica content than non-induced cells and showed a significant negative growth rate response (Table 4). In a chemostat set-up, where the growth rate is prescribed, a negative growth response will materialise as a decrease in cell concentration and an increase in the concentration of the limiting nutrient $(\mathrm{Si})$. Both of these properties differed significantly in induced vs. non-induced cells in a way consistent with a negative growth rate response of $T$. weissflogii cells (Table 4). A reduction in the maximum growth rate of induced 
compared to non-induced cells of about $20 \%$ accounts for the observed change in both steady-state cell and silica concentrations (cf. equation 1). Cell volumes decreased slightly in induced cells of both species, but none of them significantly (Table 4).

\section{Discussion}

It has long been suggested but only recently experimentally demonstrated that the silica shell in diatoms provides partial protection against copepod grazing and that the protective value increases with the silica content of the shell (Liu et al., 2016; Pančić et al., 2019). Here, we have demonstrated for seven species of diatoms and using three different approaches, that diatoms adjust this defence in response to copepod cues by thickening their shell. Although the response is quite variable, between both species and approaches, the average response is positive for all species, and significant for most (Tables 2 - 4 and Table S1). Even silicalimited cells of one of the two species examined in the chemostat experiment increased their silica content in response to grazer cues. Many other defence mechanisms are intensified in plankton in response to the presence of predator cues. These include zooplankton that modify their morphology and vertical migration patterns (De Meester et al., 1999; Lass and Spaak, 2003) and phytoplankton that intensify toxin production (Selander et al., 2006), modify colony and chain formation (Bergkvist et al., 2012; Tang, 2003; Tang et al., 2008; van Donk et al., 2011), or change their motile behaviour (Selander et al., 2011).

The response found here, up to $35 \%$ increase in silica content in response to grazer cues, is somewhat less than the response reported for the only species examined previously, $T$. weissflogii (Pondaven et al., 2007). Thalassiosira weissflogii cells doubled their silica content when growing cells were exposed to growth media that had been conditioned by feeding Calanus finmarchicus at a concentration of 40 adults $\mathrm{L}^{-1}$. This concentration corresponds to a grazer biomass at least 5 times higher than that in the copepod cultures that delivered the filtrate in our experiments. This is consistent with our further demonstration that shell thickening increases with the concentration of the copepod cue.

The observations that shell thickening can be induced and that the induction is proportional to the concentration of copepod cue both suggest that shell thickening comes with a cost: defence theory predicts that defences should be inducible when the risk is variable and the defence is costly (Tollrian and Harvell, 1999). Defence costs are often cryptic and difficult to 
quantify in phytoplankton (Pančić and Kiørboe, 2018). However, we have here demonstrated that all the species examined indeed reduce their growth rate and/or their cell volume in response to copepod cues, although the response is quite variable.

\section{Cost and benefits of shell thickening}

Below we discuss the benefits and the costs of shell thickening.

\section{Benefits}

There is now clear experimental evidence that heavily silicified cells are grazed less by small, $\mathrm{mm}$-sized copepods than lightly silicified cells, and the magnitude of the grazing reduction with silicification is consistent between the two available studies (Liu et al., 2016; Pančić et al., 2019). Pančić et al. (2019) found that copepod grazing mortality $(\delta)$ varied inversely as a power function of biogenic silica content, roughly as $\delta \sim \mathrm{Si}^{-0.79}$, with different species of diatoms following the same relation. Thus, the fractional reduction in grazing mortality $(\Delta \delta)$ varies with the fractional increase in silica content $(\Delta \mathrm{S})$ approximately according to

$$
\Delta \delta=1-(1+\Delta S)^{-0.79}
$$

The fractional increase in silica content of induced relative to non-induced cells at a nominal concentration of copepod amides of $10 \mathrm{nM}$ varied between 3-35\% with a mean of $16 \%$ (from the repeated batch experiment, Fig. 4) corresponding to a fractional decrease in grazing mortality between $2-21 \%$ (average $11 \%$ ) (from equation 2 ). This reduction in grazing mortality of induced vs. non-induced cells varies in proportion to the concentration of signal molecules and, presumably, therefore in proportion to the concentration of copepod grazers. That is, the higher the predation risk, the better protected the cells become.

It is not trivial, however, to translate our nominal concentrations of copepod signals to actual bulk concentrations of copepods and copepodamides in the ocean. The latter, however, are substantially lower than our nominal values. Thus, Selander et al. (2019) observed the actual bulk concentration of copepodamides off the Swedish west coast to vary between $40 \mathrm{fM}-$ $2 \mathrm{pM}$ over the course of a year, largely in proportion to the density of copepods. In our study, copepodamides were introduced by coating the culture flasks, which yields an effective concentration in solution about 10 times lower, and this concentration subsequently declines exponentially and rapidly. Selander et al. (2019) found the effective concentration to be just 1 
$\%$ of the nominal after 12 hours and $0.1 \%$ after $24 \mathrm{~h}$, but depending on the temperature and on the concentration and type of bacteria in suspension, this may be more or less. Thus, our experimental concentrations are much less the nominal concentration but possibly in the high end of the natural range. The experiments using copepod culture filtrate may be more in line with natural concentrations of signal molecules. The $\mathrm{CF} / \mathrm{C}$ filter removes most of the cue and the cue concentration decreases rapidly over the course of the $24 \mathrm{~h}$ induction periods.

Grazing by other zooplankton than copepods may also be impaired by elevated silica content. Similar to copepods, krill are equipped with siliceous mmouthparts that together with powerful mandibles (copepods) or gizzards (krill) appear adapted to break diatom shells (Hamm et al., 2003). However, thicker shells are less crack-able, and even krill may be unable to digest the particularly thick-shelled diatoms, such as Fragilariopsis kerguelensis, that dominate large regions of the southern Ocean (Assmy et al., 2013). Also, the siliceous mouthparts of grazers might wear down, like is known for terrestrial grass-feeders. Protistan grazers, particularly dinoflagellates, appear to feed on diatoms independent of their silica content (Pančić et al., 2019) although some species of dinoflagellates and ciliates may prefer diatoms with low silica content (Zhang et al., 2017).

\section{Costs}

Induced cells grow slower than non-induced cells, on average by $\sim 10 \%$ (repeated batch experiment), and this may represent the physiological costs of increased silification. The growth penalty may have two components, i.e., the metabolic cost of assimilating and depositing silica that allocates resources away from growth, and/or a necessary prolongation of the cell cycle to allow time for accumulating additional silica. Allocation costs are small: the synthesis cost of biogenic silica is low, about $2 \%$ of the energy content of the cell (Pančić and Kiørboe, 2018; Raven, 1983), and a $16 \%$ increase in the contents of biogenic silica would thus amount to a $16 \%$ of $2 \%=0.3 \%$ decrease in growth rate.

It is well established that diatoms limited by resources other than silica achieve a higher silica content, simply because a reduced growth rate allows more time to deposit biogenic silica (Martin-Jézéquel et al., 2000). The same allocation pattern is common in terrestrial plants that invest surplus carbon in carbon-based defence molecules when growth is limited by other nutrients, commonly referred to as the carbon nutrient balance model (Bryant et al., 1983). Data compiled for a number of diatom species grown in chemostats under limiting conditions 
(other than silica) all show the same inverse relation between growth rate $(\mu)$ and silica content (S) (Pančić et al., 2019):

$$
S \sim \mu^{-0.54}
$$

This 'passive' physiological response implies that

$$
\Delta S=1-(1+\Delta \mu)^{-0.54}
$$

Thus, an average fractional decrease in growth rate $(\Delta \mu)$ of $10 \%$ would yield an average increase in silica content of just $5 \%$, less the observed $16 \%$ average. Conversely, a $16 \%$ increase in silica content would 'require' a $31 \%$ decrease in growth rate if the response was just 'passive'. The observed growth penalty is much less, suggesting that the response to copepod cues requires some additional adaptations.

One such adaptation is a decrease in cell volume. We observed in almost all treatments that cells shrink in response to grazer cues, on average by $3.2 \%$ in volume (mean of all experiments). A decrease in cell size is one way of increasing the volume-specific silica contents of the cells. However, a $3.2 \%$ decrease in cell volume is not accounting for the higher than expected silica content in induced cell. Thus, some further adaptation in silica kinetics is necessary to account for the elevated silica content of induced cells. The fact that even silica-limited cells increase their silica content is further evidence for additional modifications of the silica kinematics in response to grazer cues.

There may be further costs to silification than what can be observed in laboratory experiments. Heavier silification may imply faster settling velocity and lower net growth rates in surface water (Raven and Waite, 2004); or, alternatively, increase the cost for buoyancy control (Gemmell et al., 2016). Smaller cells suffer higher mortality rate due to other (smaller) grazers (Kiørboe, 2008). In addition, the obligate need for silica makes diatoms competitive inferior to most other phytoplankton whenever silica becomes limiting before other inorganic nutrients, which is typically the case in regions where diatoms dominate (Pančić and Kiørboe, 2018). Finally, heavier silification of individual cells implies that a diatom bloom becomes silica limited earlier and at a lower cell concentration with 
consequently fewer resting stages formed at the end of a bloom. This represents a hidden cost of silification. However, this cost is 'public' and shared among all individuals in the population and thus not favoured by natural selection unless the diatom bloom is monoclonal (i.e., all cells stem from the same mother cell and are genetically identical siblings). Blooms of diatoms and other phytoplankton are, however, typically not monoclonal but consist of many genotypes (Godhe et al., 2016; Tammilehto et al., 2017).

\section{Trade-offs}

Are the costs of increased silification warranted by the benefits? That is, does silification increase the fitness of the cells? The currency of fitness are specific mortality and growth rates, and a change in either of the two will lead to a change in fitness. Here, we have provided rough estimates of both. Commonly used proxies of fitness are the difference between growth and mortality (Abrams, 1990), or the ratio between the two (Gillam's rule) (Gilliam and Fraser, 1987). In either case, the fractional decrease in mortality rate has to exceed the fractional decrease in growth rate for silification to be overall beneficial. On average, this appears to be the case for the scenarios examined here but the two changes are of similar magnitude; $10 \%$ and $11 \%$ respectively, at a nominal cue concentration of $10 \mathrm{nM}$. Obviously, predation mortality is expected to increase in proportion to the concentration of grazers, but so does cue concentration and shell thickening. The resulting trade-off thus appears to be near 'neutral' and the fitness landscape therefore almost flat (Ostling, 2012; Purves and Turnbull, 2010). The flat fitness landscape may explain why the responses to copepod cues are very variable, both between and within species, and highly depending on the exact experimental conditions. Such "equalizing trade-offs" also allows for prolonged coexistence of many species (Ehrlich et al., 2017; Ehrlich and Gaedke, 2018; Våge et al., 2013). Diatoms are a particularly diverse group of photosynthetic protists in the ocean (Malviya et al., 2016) and a flat fitness landscape may help account for this high diversity of coexisting species.

\section{Conclusions}

The role of silicon in diatoms resembles its role in many terrestrial plants. It serves multiple purposes, both as a cheap structural element and as a defence agent (Raven, 1983; Strömberg et al., 2016), and plays many other possible roles, both in plants (Frew et al., 2018) and in diatoms (Mitchell et al., 2013; Romann et al., 2015). In terrestrial plants, silification is 
inducible by grazers and highly variable, both within and between species (Hartley and DeGabriel, 2016; Strömberg et al., 2016), just as shown here for diatoms. While the cost of elevated silification in plants in response to grazers remains unknown, we have here demonstrated a growth penalty in diatoms to heavier silification. It is exactly such organismal trade-offs that together with environmental constraints govern the composition and function of biological communities (Chesson, 2000; Tilman, 1990; Vincent et al., 2012), including the pivotal role of diatoms in the global carbon budget (Tréguer et al., 2018).

Diatoms account for a large fraction of the biological carbon pump in the ocean (Smetacek, 1999). The defensive role of silicon in diatoms has implications to ocean biogeochemistry, not only for the fate of silicon, but also for the ability of diatoms to sequester carbon in the ocean (Assmy et al., 2013; Tréguer et al., 2018). Thus, highly defended diatoms may directly avoid grazing, while less defended thin-shelled species may escape predation by forming rapidly sinking aggregates that transport organic carbon to the ocean interior and constitute an important component of the biological pump. The silica content of like-sized diatoms varies by an order of magnitude (Pančić and Kiørboe, 2018) and unravelling the mechanisms that govern this variation is important for predicting the structure and function of phytoplankton communities, and the role of diatoms in the biological pump (Tréguer et al., 2018). Evolutionary adaptations and - as demonstrated here - plastic responses to grazers are two important factors governing the silica content of diatoms. 


\section{References}

Abrams, P.A., 1990. The Effects of Adaptive Behavior on the Type-2 Functional Response. Ecology 71, 877-885.

Aitken, Z.H., Luo, S., Reynolds, S.N., Thaulow, C., Greer, J.R., 2016. Microstructure provides insights into evolutionary design and resilience of Coscinodiscus sp. frustule. Proc. Natl. Acad. Sci. U. S. A. 113, 2017-2022. https://doi.org/10.1073/pnas.1519790113

Armbrust, E.V., 2009. The life of diatoms in the world's oceans. Nature 459, 185-192. https://doi.org/10.1038/nature08057

Assmy, P., Smetacek, V., Montresor, M., Klaas, C., Henjes, J., Strass, V.H., Arrieta, J.M., Bathmann, U., Berg, G.M., Breitbarth, E., Cisewski, B., Friedrichs, L., Fuchs, N., Herndl, G.J., Jansen, S., Krägefsky, S., Latasa, M., Peeken, I., Röttgers, R., Scharek, R., Schüller, S.E., Steigenberger, S., Webb, A., Wolf-Gladrow, D., 2013. Thick-shelled, grazer-protected diatoms decouple ocean carbon and silicon cycles in the iron-limited Antarctic Circumpolar Current. Proc. Natl. Acad. Sci. U. S. A. 110, 20633-20638. https://doi.org/10.1073/pnas.1309345110

Belgrad, B.A., Griffen, B.D., 2016. Predator-prey interactions mediated by prey personality and predator hunting mode. Proc. R. Soc. B Biol. Sci. 283. https://doi.org/10.1098/rspb.2016.0408

Bergkvist, J., Thor, P., Jakobsen, H.H., Wängberg, S.Å., Selander, E., 2012. Grazer-induced chain length plasticity reduces grazing risk in a marine diatom. Limnol. Oceanogr. 57, 318-324. https://doi.org/10.4319/lo.2012.57.1.0318

Bryant, J.P., Chapin, F.S., Klein, D.R., 1983. Carbon/nutrient balance of boreal plants in relation to vertebrate herbivory. Oikos 40, 357-368.

Cadier, M., Andersen, K.H., Visser, A.W., Kiørboe, T., 2019. Competition-defense tradeoff increases the diversity of microbial plankton communities and dampens trophic cascades. Oikos 128, 1027-1040. https://doi.org/10.1111/oik.06101

Chesson, P., 2000. Mechanisms of Maintenance of Species Diversity. Annu. Rev. Ecol. Syst. 31, 343-66. https://doi.org/10.1146/annurev.ecolsys.31.1.343

Creel, S., 2018. The control of risk hypothesis: reactive vs. proactive antipredator responses and stress-mediated vs. food-mediated costs of response. Ecol. Lett. 21, 947-956. https://doi.org/10.1111/ele.12975

De Meester, L., Dawidowicz, P., Gool, E., 1999. Ecology and evolution of predator-induced 
behavior of zooplankton: Depth selection behavior and diel vertical migration, in: Tollrian, R., Harvell, C.D. (Eds.), The Ecology and Evolution of Inducible Defences. Princeton University Press, New Jersey, pp. 160-176.

Ehrlich, E., Becks, L., Gaedke, U., 2017. Trait-fitness relationships determine how trade-off shapes affect species coexistence. Ecology 98, 3188-3198. https://doi.org/10.1002/ecy.2047

Ehrlich, E., Gaedke, U., 2018. Not attackable or not crackable-How pre- and post-attack defenses with different competition costs affect prey coexistence and population dynamics. Ecol. Evol. 8, 6625-6637. https://doi.org/10.1002/ece3.4145

Frew, A., Weston, L.A., Reynolds, O.L., Gurr, G.M., 2018. The role of silicon in plant biology: a paradigm shift in research approach. Ann. Bot. 121, 1265-1273. https://doi.org/10.1093/aob/mcy009

Gemmell, B.J., Oh, G., Buskey, E.J., Villareal, T.A., 2016. Dynamic sinking behaviour in marine phytoplankton: Rapid changes in buoyancy may aid in nutrient uptake. Proc. R. Soc. B Biol. Sci. 283. https://doi.org/10.1098/rspb.2016.1126

Gilliam, J.F., Fraser, D.F., 1987. Habitat Selection Under Predation Hazard : Test of a Model with Foraging Minnows. Ecology 68, 1856-1862.

Godhe, A., Sjöqvist, C., Sildever, S., Sefbom, J., Harardóttir, S., Bertos-Fortis, M., Bunse, C., Gross, S., Johansson, E., Jonsson, P.R., Khandan, S., Legrand, C., Lips, I., Lundholm, N., Rengefors, K.E., Sassenhagen, I., Suikkanen, S., Sundqvist, L., Kremp, A., 2016. Physical barriers and environmental gradients cause spatial and temporal genetic differentiation of an extensive algal bloom. J. Biogeogr. 43, 1130-1142. https://doi.org/10.1111/jbi.12722

Hamm, C.E., Merkel, R., Springer, O., Jurkojc, P., Maiert, C., Prechtelt, K., Smetacek, V., 2003. Architecture and material properties of diatom shells provide effective mechanical protection. Nature 421, 841-843. https://doi.org/10.1038/nature01416

Hansen, P., 2007. The red tide dinoflagellate Alexandrium tamarense: effects on behaviour and growth of a tintinnid ciliate. Mar. Ecol. Prog. Ser. 53, 105-116. https://doi.org/10.3354/meps053105

Hartley, S.E., DeGabriel, J.L., 2016. The ecology of herbivore-induced silicon defences in grasses. Funct. Ecol. 30, 1311-1322. https://doi.org/10.1111/1365-2435.12706

Karban, R., 2011. The ecology and evolution of induced resistance against herbivores. Funct. Ecol. 25, 339-347. https://doi.org/10.1111/j.1365-2435.2010.01789.x

Kiørboe, T., 2008. A Mechanistic Approach to Plankton Ecology, 1st ed. Princeton 
University Press.

Lass, S., Spaak, P., 2003. Chemically induced anti-predator defences in plankton: A review. Hydrobiologia 491, 221-239. https://doi.org/10.1023/A:1024487804497

Leibold, M.A., Hall, S.R., Smith, V.H., Lytle, D.A., 2017. Herbivory enhances the diversity of primary producers in pond ecosystems. Ecology 98, 48-56.

Lima, S.L., 1998. Nonlethal Effects in the Ecology of Predator-Prey Interactions. Bioscience 48, 25-34. https://doi.org/10.2307/1313225

Liu, H., Chen, M., Zhu, F., Harrison, P.J., 2016. Effect of diatom silica content on copepod grazing, growth and reproduction. Front. Mar. Sci. 3, 1-7. https://doi.org/10.3389/fmars.2016.00089

Malviya, S., Scalco, E., Audic, S., Vincent, F., Veluchamy, A., Poulain, J., Wincker, P., Iudicone, D., De Vargas, C., Bittner, L., Zingone, A., Bowler, C., 2016. Insights into global diatom distribution and diversity in the world's ocean. Proc. Natl. Acad. Sci. U. S. A. 113, E1516-E1525. https://doi.org/10.1073/pnas.1509523113

Martin-Jézéquel, V., Hildebrand, M., Brzezinski, M.A., 2000. Silicon metabolism in diatoms: Implications for growth. J. Phycol. 36, 821-840. https://doi.org/10.1046/j.15298817.2000.00019.x

McCauley, E., Briand, F., 1979. Zooplankton Grazing and Phytoplankton Species Richness : Field Tests of the Predation Hypothesis. Limnol. Oceanogr. 24, 243-252.

Milligan, A.J., Morel, F.M.M., 2002. A proton buffering role for silica in diatoms. Science (80-. ). 297, 1848-1850. https://doi.org/10.1126/science.1074958

Mitchell, J.G., Seuront, L., Doubell, M.J., Losic, D., Voelcker, N.H., Seymour, J., Lal, R., 2013. The Role of Diatom Nanostructures in Biasing Diffusion to Improve Uptake in a Patchy Nutrient Environment. PLoS One 8. https://doi.org/10.1371/journal.pone.0059548

Ostling, A., 2012. Do fitness-equalizing tradeoffs lead to neutral communities? Theor. Ecol. 5, 181-194. https://doi.org/10.1007/s12080-010-0107-8

Paasche, E., 1980. Silicon content of five marine plankton diatom species measured with a rapid filter method. Limnol. Oceanogr. 25, 474-480. https://doi.org/10.4319/lo.1980.25.3.0474

Paasche, E., 1973. Silicon and the ecology of marine plankton diatoms. II. Silicate-uptake kinetics in five diatom species. Mar. Biol. 19, 262-269. https://doi.org/10.1007/BF02097147

Pančić, M., Kiørboe, T., 2018. Phytoplankton defence mechanisms: traits and trade-offs 
Marina. Biol. Rev. https://doi.org/10.1111/brv.12395

Pančić, M., Torres, R.R., Almeda, R., Kiørboe, T., 2019. Silicified cell walls as a defensive trait in diatoms. Proc. R. Soc. B Biol. Sci. 286. https://doi.org/10.1098/rspb.2019.0184

Pondaven, P., Gallinari, M., Chollet, S., Bucciarelli, E., Sarthou, G., Schultes, S., Jean, F., 2007. Grazing-induced Changes in Cell Wall Silicification in a Marine Diatom. Protist 158, 21-28. https://doi.org/10.1016/j.protis.2006.09.002

Purves, D.W., Turnbull, L.A., 2010. Different but equal: The implausible assumption at the heart of neutral theory. J. Anim. Ecol. 79, 1215-1225. https://doi.org/10.1111/j.13652656.2010.01738.x

Raven, J.A., 1983. The transport and function of silicon in plants. Biol. Rev. 58, 179-207.

Raven, J.A., Waite, A.M., 2004. The evolution of silicification in diatoms: Inescapable sinking and sinking as escape? New Phytol. 162, 45-61. https://doi.org/10.1111/j.14698137.2004.01022.x

Romann, J., Valmalette, J.C., Chauton, M.S., Tranell, G., Einarsrud, M.A., Vadstein, O., 2015. Wavelength and orientation dependent capture of light by diatom frustule nanostructures. Sci. Rep. 5, 1-6. https://doi.org/10.1038/srep17403

Ryderheim, F., Selander, E., Kiørboe, T., 2020. Cost and benefits of toxin production in a dinoflagellate. bioRxiv https://doi.org/10.1101/2020.07.12.199380R

Selander, E., Berglund, E.C., Engström, P., Berggren, F., Eklund, J., Harðardóttir, S., Lundholm, N., Grebner, W., Andersson, M.X., 2019. Copepods drive large-scale traitmediated effects in marine plankton. Sci. Adv. 5, 3-9.

https://doi.org/10.1126/sciadv.aat5096

Selander, E., Jakobsen, H.H., Lombard, F., Kiørboe, T., 2011. Grazer cues induce stealth behavior in marine dinoflagellates. Proc. Natl. Acad. Sci. U. S. A. 108, 4030-4034. https://doi.org/10.1073/pnas.1011870108

Selander, E., Kubanek, J., Hamberg, M., Andersson, M.X., Cervin, G., Pavia, H., 2015. Predator lipids induce paralytic shellfish toxins in bloom-forming algae. Proc. Natl. Acad. Sci. 112, 6395-6400. https://doi.org/10.1073/pnas.1420154112

Selander, E., Thor, P., Toth, G., Pavia, H., 2006. Copepods induce paralytic shellfish toxin production in marine dinoflagellates. Proc. R. Soc. B Biol. Sci. 273, 1673-1680. https://doi.org/10.1098/rspb.2006.3502

Smetacek, V., 2001. A watery arms race. Nature 411, 745. https://doi.org/10.1038/35081210

Smetacek, V., 1999. Diatoms and the ocean carbon cycle. Protist 150, 25-32. https://doi.org/10.1016/s1434-4610(99)70006-4

This article is protected by copyright. All rights reserved 
Strickland, J.D.H., Parsons, T.R., 1972. A Practical Handbook of Seawater Analysis., 2nd ed. Fisheries Research Board of Canada, Ottawa.

Strömberg, C.A.E., Di Stilio, V.S., Song, Z., 2016. Functions of phytoliths in vascular plants: an evolutionary perspective. Funct. Ecol. 30, 1286-1297. https://doi.org/10.1111/13652435.12692

Tammilehto, A., Watts, P.C., Lundholm, N., 2017. Isolation by Time During an Arctic Phytoplankton Spring Bloom. J. Eukaryot. Microbiol. 64, 248-256. https://doi.org/10.1111/jeu.12356

Tang, K.W., 2003. Grazing and colony size development in Phaeocystis globosa (Prymnesiophyceae): The role of a chemical signal. J. Plankton Res. 25, 831-842. https://doi.org/10.1093/plankt/25.7.831

Tang, K.W., Smith, W.O., Elliott, D.T., Shields, A.R., 2008. Colony size of Phaeocystis antarctica (Prymnesiophyceae) as influenced by zooplankton grazers. J. Phycol. 44, 1372-1378. https://doi.org/10.1111/j.1529-8817.2008.00595.x

Tilman, D., 1990. Constraints and Tradeoffs: Toward a Predictive Theory of Competition and Succession. Oikos 58, 3. https://doi.org/10.2307/3565355

Tollrian, R., Harvell, C.D., 1999. The Ecology and Evolution of Inducible Defenses. Princeton University Press, New Jersey.

Tréguer, P., Bowler, C., Moriceau, B., Dutkiewicz, S., Gehlen, M., Aumont, O., Bittner, L., Dugdale, R., Finkel, Z., Iudicone, D., Jahn, O., Guidi, L., Lasbleiz, M., Leblanc, K., Levy, M., Pondaven, P., 2018. Influence of diatom diversity on the ocean biological carbon pump. Group. Nat. Geosci. 11, 27-37.

Våge, S., Bratbak, G., Egge, J., Heldal, M., Larsen, A., Norland, S., Lund Paulsen, M., Pree, B., Sandaa, R.A., Skjoldal, E.F., Tsagaraki, T.M., Øvreås, L., Thingstad, T.F., 2018. Simple models combining competition, defence and resource availability have broad implications in pelagic microbial food webs. Ecol. Lett. 21, 1440-1452. https://doi.org/10.1111/ele.13122

Våge, S., Castellani, M., Giske, J., Thingstad, T.F., 2013. Successful strategies in size structured mixotrophic food webs. Aquat. Ecol. 47, 329-347. https://doi.org/10.1007/s10452-013-9447-y

van Donk, E., Ianora, A., Vos, M., 2011. Induced defences in marine and freshwater phytoplankton: A review. Hydrobiologia 668, 3-19. https://doi.org/10.1007/s10750-0100395-4

Vincent, T.., Scheel, D., Brown, J.., Vincent, T., 2012. Trade-Offs and Coexistence in 
Consumer-Resource Models. Am. Nat. Na 148, 1038-1058.

Wilken, S., Hoffmann, B., Hersch, N., Kirchgessner, N., Dieluweit, S., Rubner, W.,

Hoffmann, L.J., Merkel, R., Peeken, I., 2011. Diatom frustules show increased mechanical strength and altered valve morphology under iron limitation. Limnol.

Oceanogr. 56, 1399-1410. https://doi.org/10.4319/lo.2011.56.4.1399

Zhang, S., Liu, H., Ke, Y., Li, B., 2017. Effect of the silica content of diatoms on protozoan grazing. Front. Mar. Sci. 4. https://doi.org/10.3389/fmars.2017.00202

Tables

Table 1: Experimental information. The table lists the experimental design of experiment together with the tested species, the duration and the source of copepod cues.

\begin{tabular}{clll}
\hline Experiment nr. & Species & Duration & Copepod cues \\
\hline Repeated batch experiments & & & \\
1 & D. brightwellii or T. weissflogii & 11 days & Filtrate \\
2 & C. cryptica or C. meneghiniana & 7 days & Copepodamides \\
3 & A. paludosa or D. brightwellii & 8 days & Copepodamides
\end{tabular}

Dose-response experiments

$\begin{array}{llll}4 & \text { C. cryptica or } \text { T. weissflogii } & 48 \text { hours } & \text { Copepodamides } \\ 5 & \text { C. cryptica } \text { or } \text { C. meneghiniana } & 48 \text { hours } & \text { Copepodamides } \\ 6 & \text { N. incerta or } \text { N. laevis } & 48 \text { hours } & \text { Copepodamides } \\ 8 & \text { A. paludosa } \text { or } \text { D. brightwellii } & 48 \text { hours } & \text { Copepodamides }\end{array}$

Continuous culture

experiments

\begin{tabular}{cccc}
9 & T. weissflogii & 5 days & Copepodamides \\
10 & A. paludosa & 5 days & Copepodamides \\
\hline
\end{tabular}

Table 2: Dose-response experiment. Percentage difference in silica content, growth rate and cell volume between lowest $(0$ $n M)$ and highest (10 nM) concentration of copepodamides based on their regressions. Differences are relative to control treatments, i.e. positive or negative differences means an increase or decrease in induced cells, respectively. ${ }^{*} p<0.05$; ${ }^{*} p$ $<0.01$ and $* * * p<0.001$.

\begin{tabular}{lccccc}
\hline Species & $\Delta$ Silica $\left(\mu \mathrm{m}^{-3}\right)$ & \multicolumn{2}{c}{$\Delta$ Growth $\left(\mathrm{d}^{-1}\right)$} & \multicolumn{2}{c}{$\Delta$ Volume $\left(\mu \mathrm{m}^{3}\right)$} \\
& $48 \mathrm{~h}$ & $0-24 \mathrm{~h}$ & $24-48 \mathrm{~h}$ & $24 \mathrm{~h}$ & $48 \mathrm{~h}$ \\
\hline T. weissflogii & 2.7 & $-12.4 *$ & -11.1 & -0.5 & -2.1 \\
A. paludosa & $27.3 * * *$ & $-85.5 *$ & 45.2 & $-3.4 *$ & $-11.9 *$ \\
\hline
\end{tabular}




\begin{tabular}{lccccc}
\hline D. brightwellii & $23.1 * * *$ & 9.8 & 3.1 & -1.6 & $-3.3 * * *$ \\
$N$. laevis & $35.6 * * *$ & -66.7 & -32.7 & -9.1 & 2.8 \\
$N$. incerta & $9.5 *$ & $-90.2 * *$ & -5.7 & -1.0 & 11.1 \\
C. cryptica & $17.3 *$ & 4.0 & 13.4 & -14.4 & $-9.7^{*}$ \\
C. meneghiniana & $15.2 *$ & -2.1 & -3.9 & -2.0 & $-7.4 *$ \\
\hline
\end{tabular}

This article is protected by copyright. All rights reserved 
Table 3: The relative difference between induced and non-induced cells (\%), averaged over the time course of each repeated batch experiment, in silica content, growth rate, and cell volume. Positive differences reflect increase in induced cells, and vice versa. Differences are presented as means $\pm S D$ (number of samples). * $p<0.05 ; * * p<0.01$ and ***p $<0.001$.

\begin{tabular}{lccc}
\hline Species & $\begin{array}{c}\Delta \text { Silica } \\
\left(\mu \mathrm{m}^{-3}\right)\end{array}$ & $\begin{array}{c}\Delta \text { Growth } \\
\left(\mathrm{d}^{-1}\right)\end{array}$ & $\begin{array}{c}\Delta \text { Volume } \\
\left(\mu \mathrm{m}^{3}\right)\end{array}$ \\
\hline T. weissflogii $(F)$ & $4.9 \pm 5.3 *(20)$ & $-13.3 \pm 12.2 *(20)$ & $0.1 \pm 2.0(20)$ \\
A. paludosa & $6.8 \pm 13.8(14)$ & $1.4 \pm 7.0(14)$ & $-0.5 \pm 4.4(14)$ \\
D. brightwellii $(F)$ & $19.3 \pm 28.1(16)$ & $-34.3 \pm 33.8 * *(16)$ & $-0.1 \pm 3.6 *(16)$ \\
D. brightwellii & $15.8 \pm 10.0 * *(14)$ & $0.9 \pm 20.4(14)$ & $-3.9 \pm 2.7 * *(14)$ \\
C. cryptica & $24.7 \pm 9.6 * *(12)$ & $0.5 \pm 4.3(12)$ & $-6.1 \pm 2.5 * * *(12)$ \\
C. meneghiniana & $34.8 \pm 9.4 * * *(12)$ & $-9.4 \pm 10.0 *(12)$ & $-3.1 \pm 1.3 * * *(12)$ \\
\hline
\end{tabular}

Table 4: Average percentage difference between control and induced treatments in continuous culture experiments.

Differences is based on control treatment, i.e. positive or negative differences means an increase or decrease in induced cells, respectively. Differences are presented as means $\pm S D(n) * p<0.05 ; * * p<0.01$ and $* * * p<0.001$.

\begin{tabular}{lcccc}
\hline Species & $\begin{array}{c}\Delta \text { Biogenic Silica } \\
\left(\mu \mathrm{m}^{-3}\right)\end{array}$ & $\begin{array}{c}\Delta \text { Cell conc. } \\
\left(\mathrm{mL}^{-1}\right)\end{array}$ & $\begin{array}{c}\Delta \text { Volume } \\
\left(\mu \mathrm{m}^{3}\right)\end{array}$ & $\begin{array}{c}\Delta \text { Dissolved silica } \\
\left(\mathrm{mL}^{-1}\right)\end{array}$ \\
\hline T. weissflogii & $9.6 \pm 4.4 * *(12)$ & $-23.4 \pm 16.3 * *(12)$ & $-9.0 \pm 27.1(12)$ & $37.5 \pm 23.9 *(12)$ \\
A. paludosa & $4.1 \pm 22.6(12)$ & $5.2 \pm 15.0(12)$ & $4.0 \pm 17.3(12)$ & $-29.5 \pm 10.1(12)$ \\
\hline
\end{tabular}


Figures
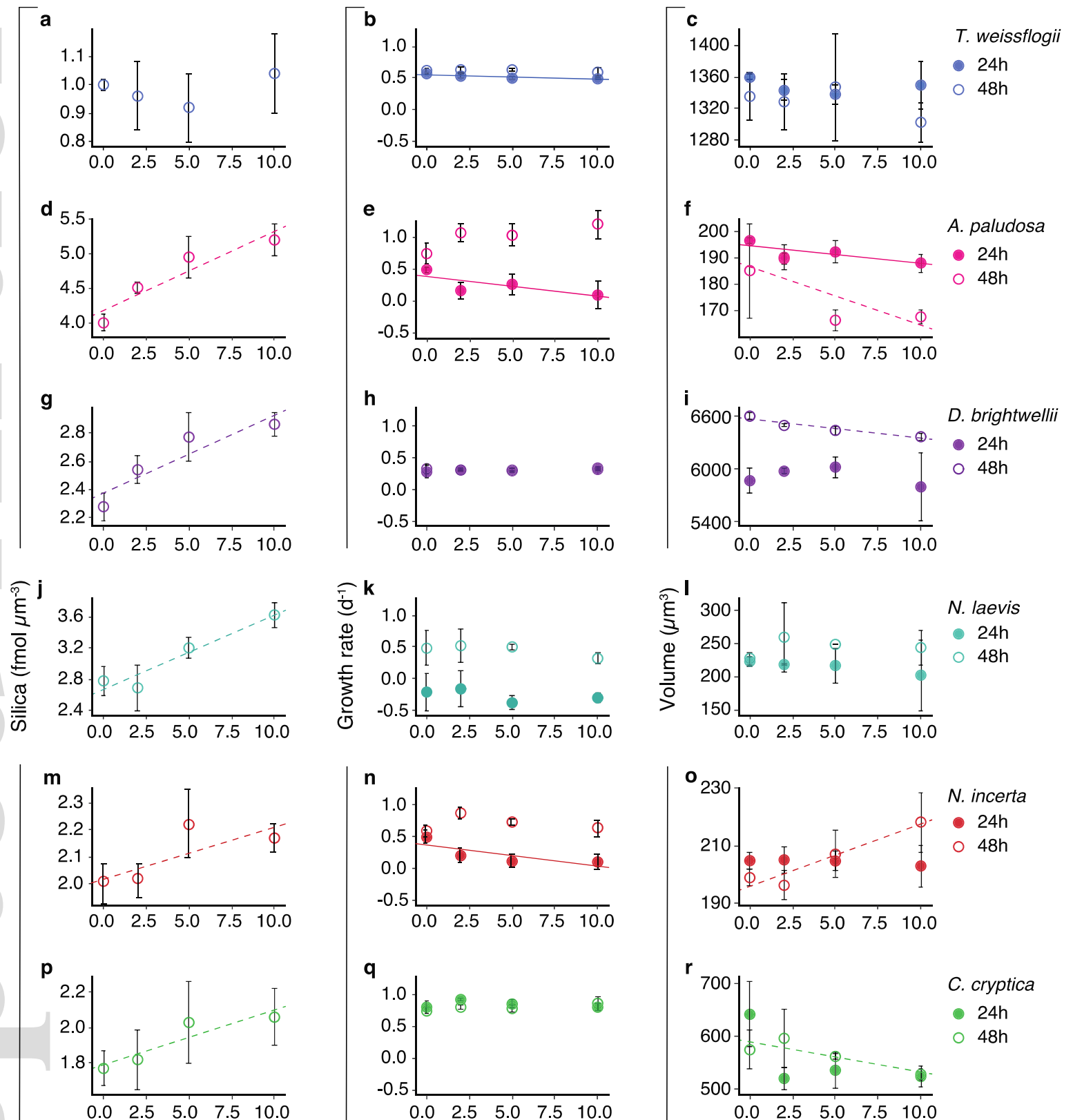

q
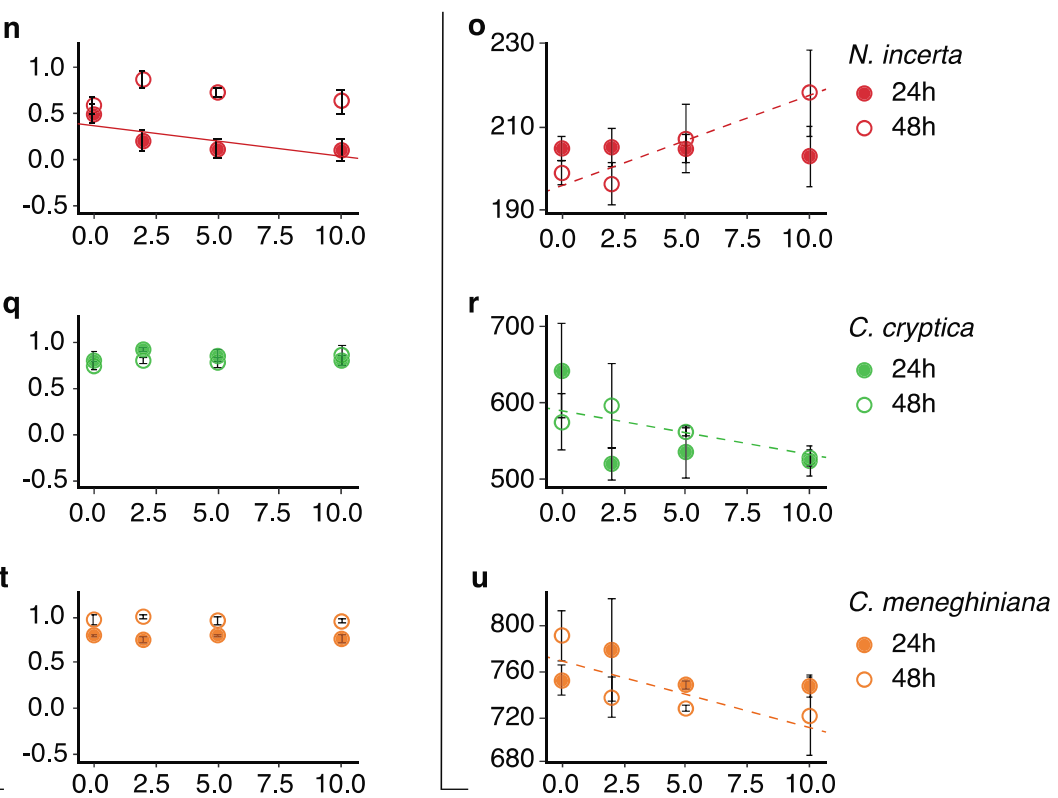

Nominal copepodamide conc. (nM) 
Fig. 1: Relationship between copepodamide concentration and silica (left column), growth rate (mid column) and cell volume (right column). Points represents the mean of triplicates, and error bars the standard deviation. Each row represents the species present in the legend of that row. Dots and open circles colours represent samples taken after $24 \mathrm{~h}$ and $48 \mathrm{~h}$, respectively. Solid and dashed lines denote linear regressions for $24 \mathrm{~h}$ and $48 \mathrm{~h}$ and are plotted in cases where they were statistically significant $(p>0.05)$. Note the different scales on y-axis.
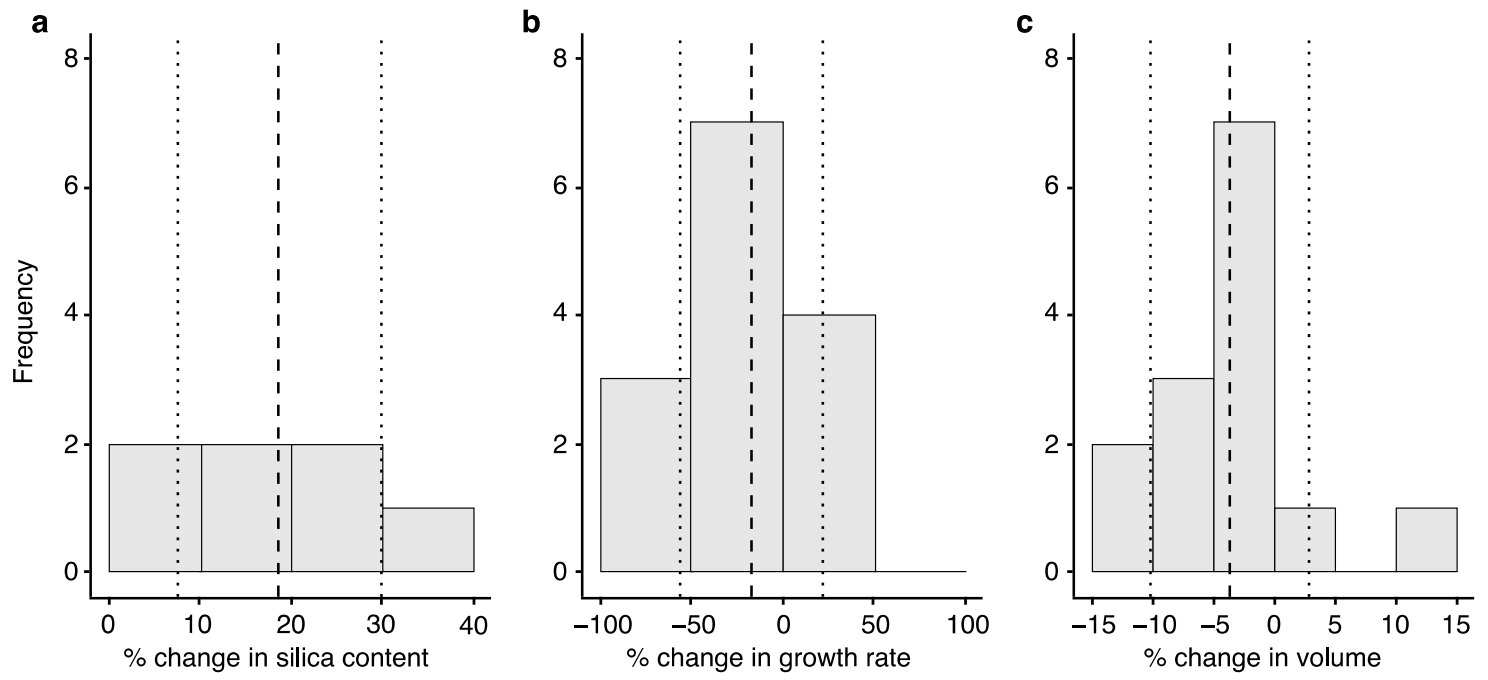

Fig. 2: Frequency distribution of percent change in silica content (a), growth rate (b) and cell volume (c) of all species in the dose-response experiments. The dashed line represents the overall mean and the dotted lines its standard deviation. Mean percent change in silica content, growth rate and cell volume are $18.7 \pm 11.6,-17.3 \pm 38.7$ and $-3.8 \pm 6.5$, respectively. 


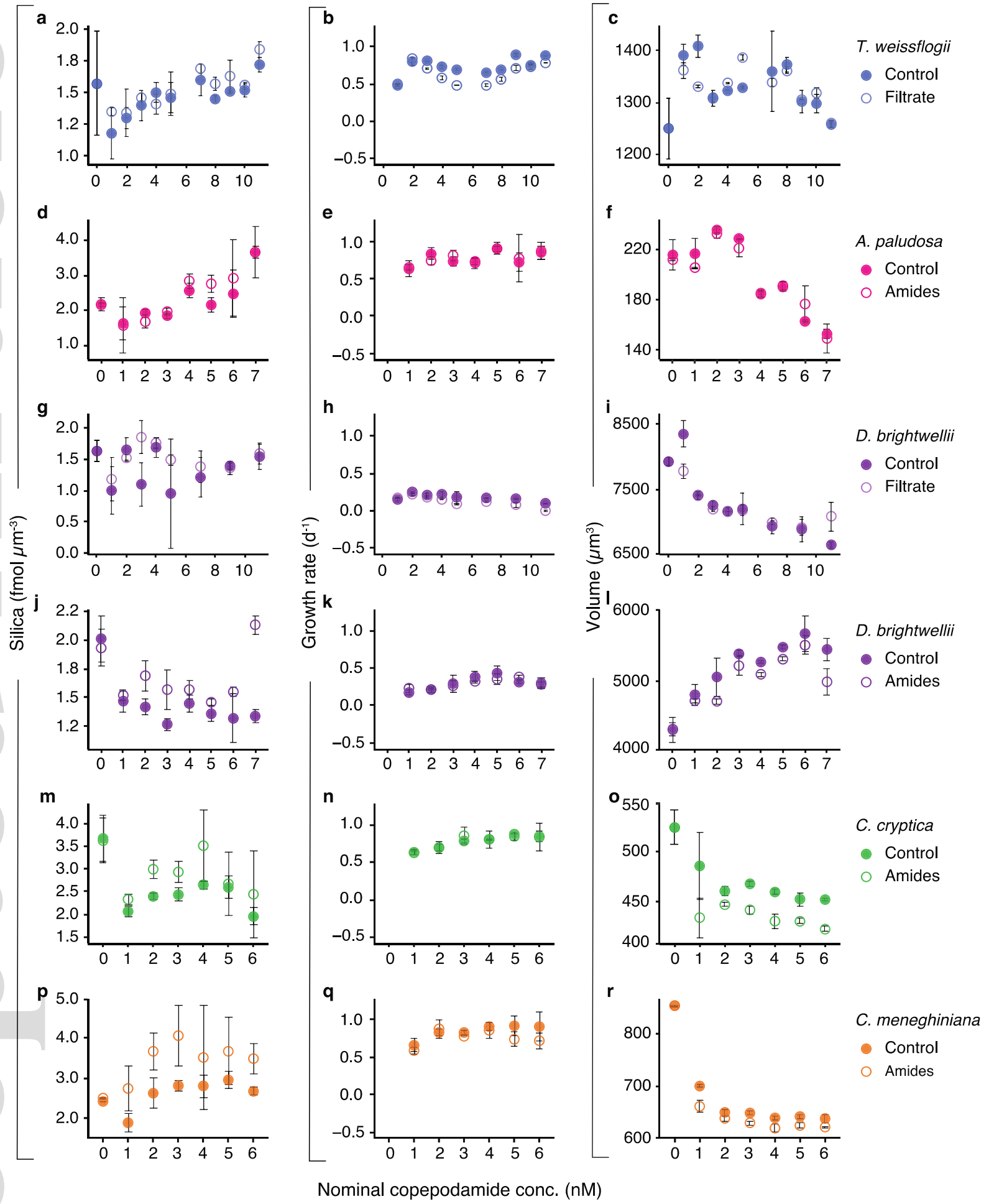

Fig. 3: Variation in silica content (left column), growth rate (mid column) and cell volume (right column) over time of induced (open circles) and non-induced (dots) cells in repeated batch experiments. Points represents the mean of triplicates, and error bars the standard deviation. Each row represents the species present in the legend of that row. Note the different scales on y-axis. 

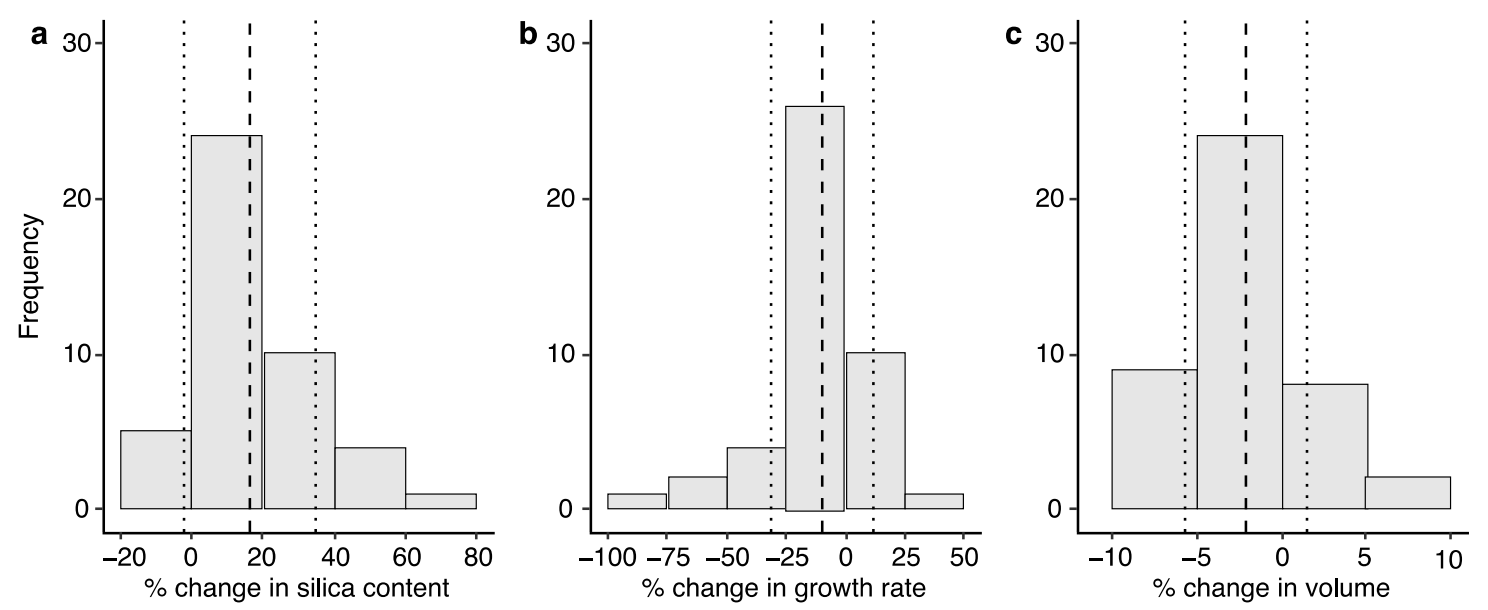

Fig. 4: Frequency distribution of percent change in silica content (a), growth rate (b) and cell volume (c) of all species in the repeated batch experiments. The dashed line represents the overall mean and the dotted lines its standard deviation. Mean percent change in silica content, growth rate and cell volume are $16.3 \pm 18.2,-10.1 \pm 21.5$ and $-2.1 \pm 3.6$, respectively.
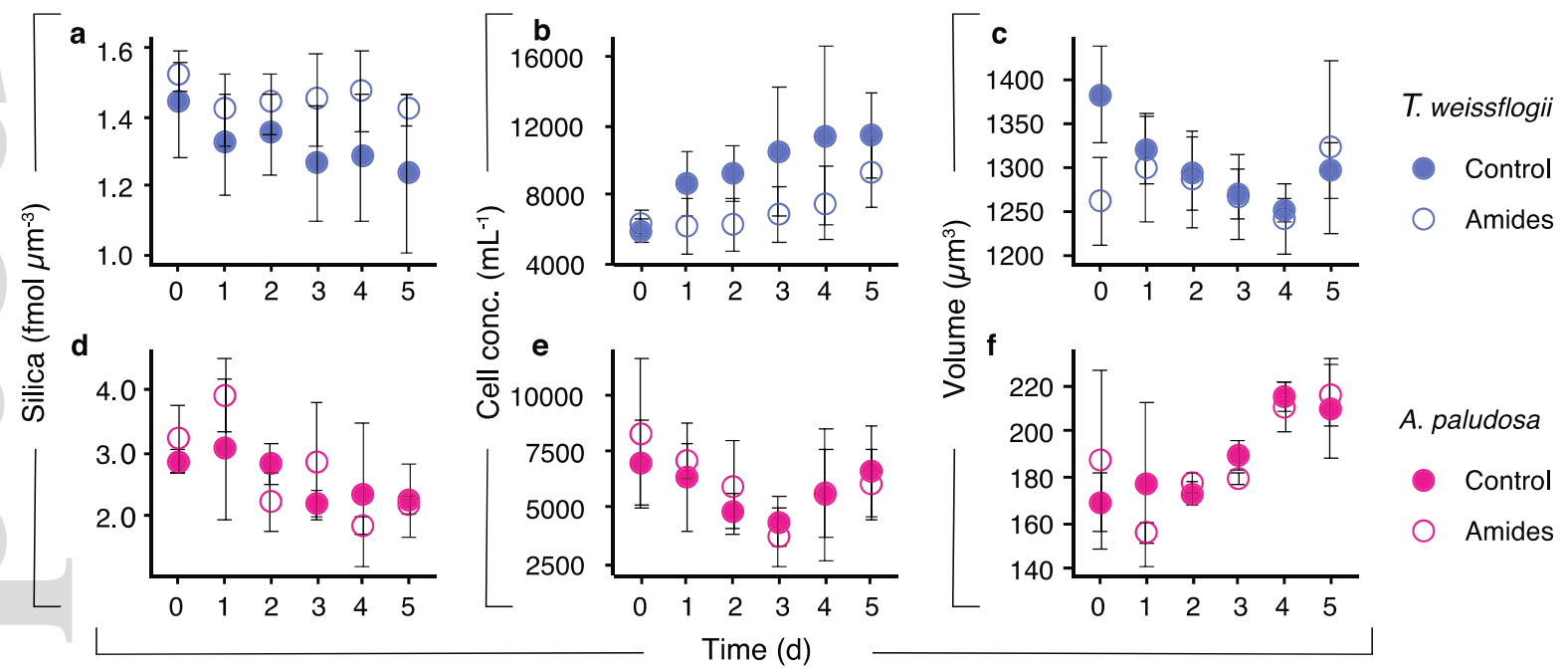

Fig. 5: Silica (left column), growth rate (mid column) and cell volume (right column) over time of induced (open circles) and non-induced (dots) cells. Each row represents the species present in the legend of that row. 